\title{
Synthesis and Antimicrobial Activity of Some New Thiazolidin-4-one Derivatives of 4-(6-methylbenzo[d]thiazol-2-yl)benzamine
}

\author{
Awaz Jamil Hussein and Hashim Jalal Azeez \\ Department of Chemistry, College of Education-Scientific Deptartment, Salahaddin University, Hawler, Kurdistan, Arbil, Iraq \\ Correspondence should be addressed to Awaz Jamil Hussein; awazjhusen@yahoo.com
}

Received 27 June 2012; Accepted 8 October 2012

Academic Editor: Heng Jiang

Copyright (C) 2013 A. J. Hussein and H. Jalal Azeez. This is an open access article distributed under the Creative Commons Attribution License, which permits unrestricted use, distribution, and reproduction in any medium, provided the original work is properly cited.

\begin{abstract}
A number of derivatives of 2-(substituted phenyl)-3-(4-(6-methylbenzo[d]thiazol-2-yl)phenyl) thiazolidin-4-one (3a-j) have been synthesized from the reaction of 4-(6-methylbenzo[d]thiazol-2-yl)benzenamine(1), with different substituted benzaldehydes $(2 \mathrm{a}-\mathrm{j})$, followed by cyclocondensation reaction of the prepared imines with 2-meraptoacetic acid in high yields. Furthermore, the structures of the newly synthesized compounds were confirmed by FT-IR, ${ }^{13} \mathrm{C}-\mathrm{NMR},{ }^{13} \mathrm{C}-\mathrm{DEPT}$, and ${ }^{1} \mathrm{H}-\mathrm{NMR}$ spectral data. The imines and thiazolidin-4-one derivatives were evaluated for their antibacterial activity against Escherichia coli as gram negative and Staphylococcus aureus as gram positive, the results have shown significant activity against both types of bacteria.
\end{abstract}

\section{Introduction}

Imines can easily be prepared from amines and benzaldehydes $[1,2]$ and are useful precursor for the synthesis of different heterocyclic compounds like azetidinones $[3,4]$ and thiazolidin-4-ones [5-7]. Thiazolidin-4-ones are one of the most intensively investigated classes of aromatic hetrocycles, containing sulfur and nitrogen in five-membered rings, these compounds can be prepared from imines and 2mercaptoacetic acid [8]. Both imines and thiazolidin-4-one are known to possess impressive biological activities such as antibacterial $[9,10]$, antihyperglycemia [11], antifungal [12, 13], antagonist [14], insecticidal [15], anticonvulsant [16], and antitubercular agents [17]. Therefore it was envisaged that compounds containing both thiazole and thiazolidin4-one moieties would have interesting biological activities [18]. In the present work, we have described the synthesis of some new thiazolidin-4-one compounds derived from 4(6-methylbenzo[d]thiazol-2-yl)benzenamine, evaluating the effect of electron donating and electron withdrawing substituents, the biological activity and their spectroscopic studies were also investigated.

\section{Experimental}

Melting points were determined using an electrothermal melting point apparatus. IR spectra were recorded on a BioRad Merlin FT-IR spectroscopy Mod FTS 3000, using $\mathrm{KBr}$ disc. ${ }^{1} \mathrm{H}$-NMR and ${ }^{13} \mathrm{C}$-NMR and ${ }^{13} \mathrm{C}$-DEPT-135 spectra were recorded on a Bruker $(300 \mathrm{MHz})$ with TMS as internal reference.

2.1. Synthesis of Imines: (Substituted benzylidene)-4-(6-methylbenzo[d] thiazol-2-yl)benzenamine (2a-j) [19]. According to the modified procedure, imines $(2 \mathrm{a}-\mathrm{j})$ were synthesized by dissolving (2.4 g, $0.01 \mathrm{~mol})$ of 4-(6-methylbenzo[d]thiazol2-yl)benzenamine (1) in $96 \%$ ethanol $(20 \mathrm{~mL})$, and mixed with the solution of an appropriate substituted benzaldehyde $(0.01 \mathrm{~mol})$ in $96 \%$ ethanol $(10 \mathrm{~mL})$ with a few drops of acetic acid. The mixture was refluxed for (1-3 hrs) until the formation of imines which was monitored by TLC and formation of solid products. The cooled mixture was filtered, dried, and purified by hot ethanol to give pure crystals of compounds $(2 a-j)$. 


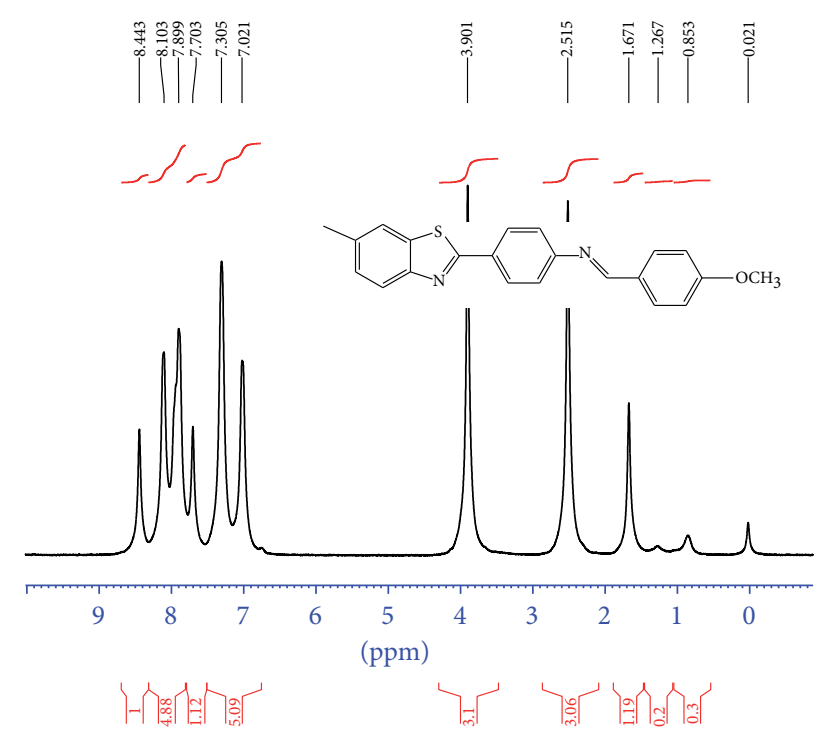

FIgURE 1: ${ }^{1} \mathrm{H}-\mathrm{NMR}$ spectrum of compound (2g).
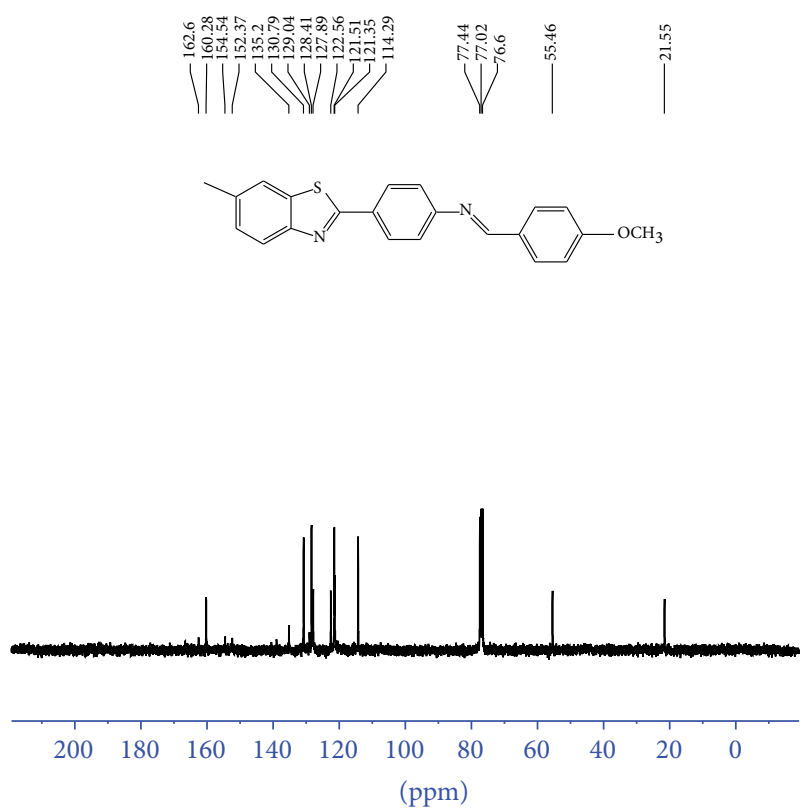

Figure 2: ${ }^{13} \mathrm{C}$-NMR spectrum of compound (2g).

2a: R: $\mathrm{H}, \mathrm{C}_{21} \mathrm{H}_{16} \mathrm{~N}_{2} \mathrm{~S}, \mathrm{mp} \cdot 194-196^{\circ} \mathrm{C}$, yield: $80 \%$. FT-IR $\left(\mathrm{KBr} \mathrm{cm}^{-1}\right): 3016,2912,2885,1624,1565,1500,1481$.

2b: R: $4-\mathrm{Cl}, \mathrm{C}_{21} \mathrm{H}_{15} \mathrm{ClN}_{2} \mathrm{~S}$, mp. $226-228^{\circ} \mathrm{C}$, yield: $84 \%$. FT-IR $\left(\mathrm{KBr} \mathrm{cm}^{-1}\right): 3020,2913,2863,1624,1580$, $1562,1483$.

2c: R: 3-Cl, $\mathrm{C}_{21} \mathrm{H}_{15} \mathrm{ClN}_{2} \mathrm{~S}$, mp. $206-208^{\circ} \mathrm{C}$, yield: $85 \%$. FT-IR $\left(\mathrm{KBr} \mathrm{cm}^{-1}\right): 3017,2910,2880,1628,1605$, 1595.

2d: R: 2- $\mathrm{NO}_{2}, \mathrm{C}_{21} \mathrm{H}_{15} \mathrm{~N}_{3} \mathrm{O}_{2} \mathrm{~S}, \mathrm{mp} .208-210^{\circ} \mathrm{C}$, yield: $80 \%$. FT-IR $\left(\mathrm{KBr} \mathrm{cm}^{-1}\right)$ : 3022, 2913, 2881, 1615, 1607, 1580, 1512, 1377.
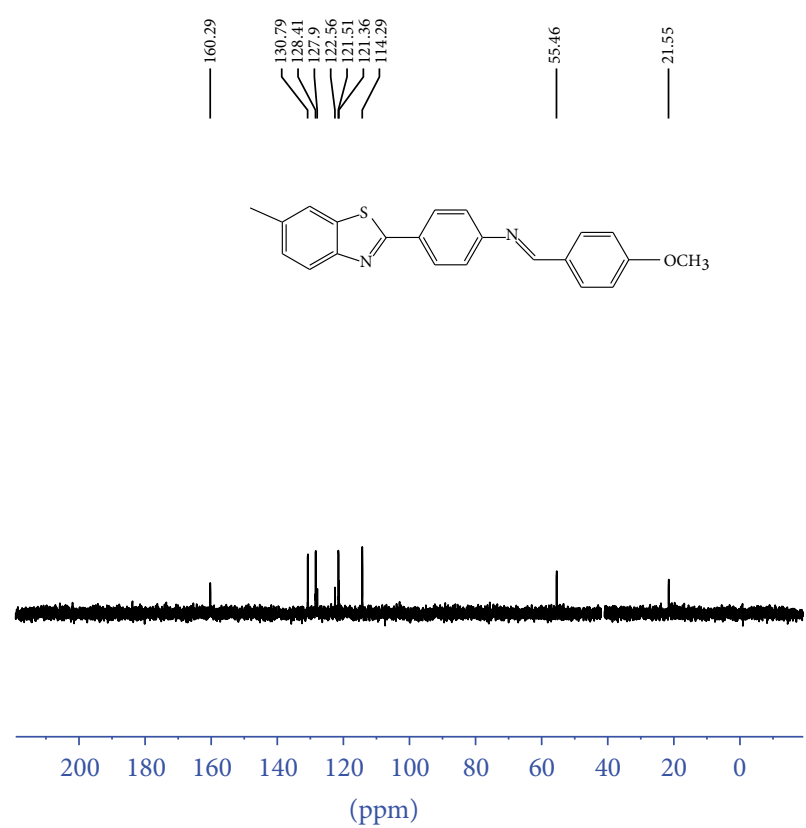

FIGURE 3: Dept-135 spectrum of compound (2g).

2e : R: $2-\mathrm{F}, \mathrm{C}_{21} \mathrm{H}_{15} \mathrm{FN}_{2} \mathrm{~S}, \mathrm{mp} .139-141^{\circ} \mathrm{C}$, yield: $83 \%$. FTIR $\left(\mathrm{KBr} \mathrm{cm}^{-1}\right)$ : 3023, 2924, 2854, 1627, 1603, 1590.

2f: R: 4- $\mathrm{NO}_{2}, \mathrm{C}_{21} \mathrm{H}_{15} \mathrm{~N}_{3} \mathrm{O}_{2} \mathrm{~S}, \mathrm{mp} .223-224^{\circ} \mathrm{C}$, yield: $88 \%$. FT-IR $\left(\mathrm{KBr} \mathrm{cm}{ }^{-1}\right)$ : 3019, 2916, 2865, 1629, 1599, 1510, 1512, 1340.

2g: R: $4-\mathrm{OCH}_{3}, \mathrm{C}_{22} \mathrm{H}_{18} \mathrm{~N}_{2} \mathrm{OS}, \mathrm{mp} .188-190^{\circ} \mathrm{C}$, yield: 75\%. FT-IR $\left(\mathrm{KBr} \mathrm{cm}^{-1}\right): 3016,2910,1609,1570,1251$, 1028; ${ }^{1} \mathrm{H}-\mathrm{NMR} 2.51\left(\mathrm{~s}, 3 \mathrm{H}, \mathrm{CH}_{3}\right), 3.9\left(\mathrm{~s}, 3 \mathrm{H},-\mathrm{OCH}_{3}\right)$, 7.02-8.1 (m, $11 \mathrm{H}$, for aromatic ring, $8.44(\mathrm{~s}, 1 \mathrm{H}$, imine proton $-\mathrm{CH}=\mathrm{N}-) ;{ }^{13} \mathrm{C}-\mathrm{NMR}: 21.55:\left(\mathrm{CH}_{3}\right) ; 55.46$ : $\left(\mathrm{O}-\mathrm{CH}_{3}\right) ; 114.2: \mathrm{C}_{2^{\prime}, 2} ; 121: \mathrm{C}_{12} ; 121.5: \mathrm{C}_{15} ; 122.5$ : $\mathrm{C}_{7,7^{\prime}} ; 127.8: \mathrm{C}_{14} ; 128.41: \mathrm{C}_{4} ; 129.00: \mathrm{C}_{8,8^{\prime}} ; 130.79$ : $\mathrm{C}_{3,3^{\prime}} ; 135.2: \mathrm{C}_{9} ; \quad 138: \mathrm{C}_{13} ; 139: \mathrm{C}_{11} ; 152.37: \mathrm{C}_{16}$; $154.54: \mathrm{C}_{6} ; \quad 160.28: \mathrm{C}_{5} ; \quad 162.6: \mathrm{C}_{1} ; \quad 165.5: \mathrm{C}_{10}$; Dept-135:21.55: $\mathrm{CH}_{3} ; \quad 55.46:-\mathrm{OCH}_{3} ; 114.2: \mathrm{C}_{2^{\prime}, 2}$; $121.3: \mathrm{C}_{12} ; \quad 121.5: \mathrm{C}_{15} ; \quad 122.5: \mathrm{C}_{7^{\prime}, 7} ; \quad 127.8: \mathrm{C}_{14}$; $129.00: \mathrm{C}_{8^{\prime}, 8} ; 160.28: \mathrm{C}_{5}$.

2h: R: $4-\mathrm{CH}_{3}, \mathrm{C}_{22} \mathrm{H}_{18} \mathrm{~N}_{2} \mathrm{~S}, \mathrm{mp} .193-195^{\circ} \mathrm{C}$, yield: $74 \%$. FT-IR $\left(\mathrm{KBr} \mathrm{cm}^{-1}\right)$ : 3026, 2914, 2856, 1629, 1593, $1568,1477$.

2i: R: $-\mathrm{CHO}, \mathrm{C}_{22} \mathrm{H}_{16} \mathrm{~N}_{2} \mathrm{OS}, \mathrm{mp} .225-227^{\circ} \mathrm{C}$, yield: $80 \%$. FT-IR (KBr): 3024, 2916, 2852, 2738, 1697, 1605,1562, 1479; ${ }^{1} \mathrm{H}-\mathrm{NMR} ; 2.52$ (s, $\left.3 \mathrm{H}, \mathrm{CH}_{3}\right), 10.1$ (s,1H,-CHO), 7.2-8.1 $(\mathrm{m}, 11 \mathrm{H}$, for aromatic rings), $8.6(\mathrm{~s}, 1 \mathrm{H}$, imine proton $-\mathrm{CH}=\mathrm{N}-)$; ${ }^{13} \mathrm{C}-\mathrm{NMR}: 21.56\left(\mathrm{CH}_{3}\right)$; $121.36: \mathrm{C}_{12} ; 121.58: \mathrm{C}_{15} ; 122.68: \mathrm{C}_{7^{\prime}, 7} \quad 128.05: \mathrm{C}_{14}$; $128.5: \mathrm{C}_{8,8^{\prime}} ; 129.45: \mathrm{C}_{3^{\prime}, 3} ; 130.07: \mathrm{C}_{2,2} ; 132.14: \mathrm{C}_{9}$; $135.45: \mathrm{C}_{13} ; \quad 138.23: \mathrm{C}_{11} ; \quad 140.9: \mathrm{C}_{1,4} ; \quad 153.3: \mathrm{C}_{16}$; $159.4: \mathrm{C}_{5} ; \quad 164.0: \mathrm{C}_{10} ; \quad 191.70: \mathrm{CHO} ; \quad$ Dept-135: $21.56\left(\mathrm{CH}_{3}\right) ; 121.36: \mathrm{C}_{12} ; 121.58: \mathrm{C}_{15} ; 122.68: \mathrm{C}_{7^{\prime}, 7}$; $128.05: \mathrm{C}_{14} ; 128.5: C_{8^{\prime}, 8} ; 129.45: C_{3^{\prime}, 3} ; 130.07: C_{2^{\prime}, 2}$; $159.4: \mathrm{C}_{5} ; 191.7: \mathrm{CHO}$. 


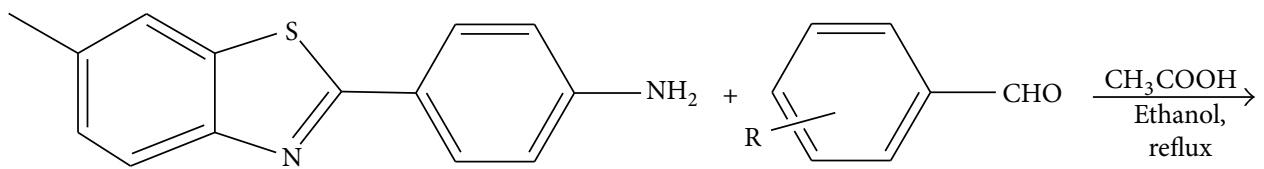

$(1)$

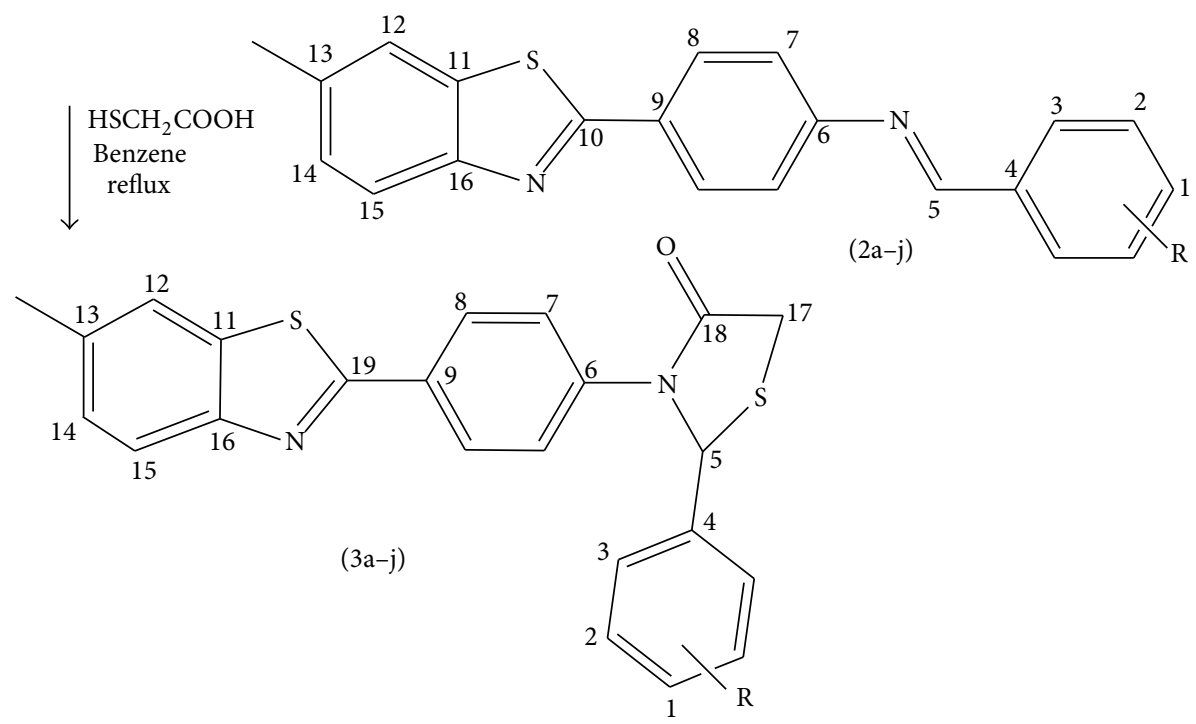

R: $\mathrm{H}, 4-\mathrm{Cl}, 3-\mathrm{Cl}, 2-\mathrm{NO}_{2}, 3-\mathrm{NO}_{2}, 4-\mathrm{NO}_{2}, 2-\mathrm{F}, 4-\mathrm{CH}_{3}, 4-\mathrm{OCH}_{3} 4-\mathrm{CHO}$

SCHEME 1

2j: R: 3- $\mathrm{NO}_{2}, \mathrm{C}_{21} \mathrm{H}_{15} \mathrm{~N}_{3} \mathrm{O}_{2} \mathrm{~S}, \mathrm{mp} .201-203^{\circ} \mathrm{C}$, yield: $81 \%$. FT-IR $\left(\mathrm{KBr} \mathrm{cm}^{-1}\right)$ : 3019, 2920, 2887, 1625, 1597, $1566,1519,1342$.

2.2. Synthesis of Thiazolidin-4-ones: 3-(4-(6Methylbenzo[d]thiazol-2-yl)phenyl)-2-(4-substitutedphenyl) Thiazolidin-4-ones (3a-j) [20]. According to the modified procedure,a mixture of imine $(0.005 \mathrm{~mol})$ and 2 -mercaptoacetic acid $(0.006 \mathrm{~mol})$ in benzene $(20 \mathrm{~mL})$ was refluxed with stirring for $(12 \mathrm{hrs})$. The solvent was removed by using rotary evaporator. The remaining solid compound was neutralized by adding cold saturated sodium bicarbonate and allowed to stand overnight. The solid products were isolated by suction filteration,washed with water, dried, and then purified by flash chromatography $\left(\mathrm{CHCl}_{3}\right)$.

3a: R: $\mathrm{H}, \mathrm{C}_{23} \mathrm{H}_{18} \mathrm{~N}_{2} \mathrm{OS}_{2}$, mp. $232-234^{\circ} \mathrm{C}$, yield: $70 \%$. FTIR $\left(\mathrm{KBr} \mathrm{cm}^{-1}\right)$ : 3021, 2930, 2845, 1667, 1606, 1510.

3b: R: 4-Cl, $\mathrm{C}_{23} \mathrm{H}_{17} \mathrm{ClN}_{2} \mathrm{OS}_{2}, \mathrm{mp} .146-148^{\circ} \mathrm{C}$, yield: 65\%. FT-IR $\left(\mathrm{KBr} \mathrm{cm} \mathrm{cm}^{-1}\right): 3030,2966,2851,1699$, 1600, 1478; ${ }^{1} \mathrm{H}-\mathrm{NMR}: 2.56$ : (s, 3H, $\left.\mathrm{CH}_{3}\right) ; 3.91,4.0$ $\left(\mathrm{dd}, 2 \mathrm{H}, \mathrm{C}_{17}\right) ; 6.19\left(\mathrm{~s}, \mathrm{H}, \mathrm{C}_{5}\right) ; 7.6:\left(\mathrm{s}, \mathrm{H}, \mathrm{C}_{12}\right) ; 8.08$ $\left(\mathrm{d}, 2 \mathrm{H}, \mathrm{C}_{8,8^{\prime}}\right) ; 7.8\left(\mathrm{~d}, \mathrm{H}, \mathrm{C}_{15}\right) ; 7.18-7.35(\mathrm{~m}, 7 \mathrm{H}$, for $\left.-\mathrm{C}_{2,2^{\prime}} ; \mathrm{C}_{3^{\prime}, 3} ; \mathrm{C}_{7,7^{\prime}} ; \mathrm{C}_{14}\right) ; 7.18-8.08(\mathrm{~m}, 11 \mathrm{H}$, for aromatic proton); ${ }^{13} \mathrm{C}-\mathrm{NMR}: 21.5: \mathrm{CH}_{3} ; 33.5: \mathrm{C}_{17}$; $64.53: \mathrm{C}_{5} ; \quad 121.37: \mathrm{C}_{12} ; \quad 122.7: \mathrm{C}_{15} ; 125.3: \mathrm{C}_{7,7^{\prime}}$; $128.0: \mathrm{C}_{14} ; 128.18: \mathrm{C}_{8,8^{\prime}} ; 128.3: \mathrm{C}_{2,2} ; 129.3: \mathrm{C}_{3^{\prime}, 3}$;
$132.1:\left(\mathrm{C}_{9}\right) ; 134.9: \mathrm{C}_{1} ; 135.2: \mathrm{C}_{13} ; 135.6: \mathrm{C}_{11} ; 137.5:$ $\mathrm{C}_{4} ; \quad 139.3: \mathrm{C}_{6} ; \quad 152.18: \mathrm{C}_{16} ; 165.6: \mathrm{C}_{10} ; 170.9:$ $\mathrm{C}_{18},(-\mathrm{C}=\mathrm{O})$; Dept-135: $21.5: \mathrm{CH}_{3} ; 33.5: \mathrm{C}_{17} ; 64.53$ : $\mathrm{C}_{5} ; 121.37: \mathrm{C}_{12} ; 122.7: \mathrm{C}_{15} ; 125.3: \mathrm{C}_{7,7^{7}} ; 128.0: \mathrm{C}_{15}$; $128.18: \mathrm{C}_{8,8^{\prime}} ; 128.3: \mathrm{C}_{7,7^{\prime}} ; 129.3: \mathrm{C}_{3^{\prime}, 3}$;

3c: R: 3-Cl, $\mathrm{C}_{23} \mathrm{H}_{17} \mathrm{ClN}_{2} \mathrm{OS}_{2}$, mp. 195-197 C, yield: $70 \%$. FT-IR $\left(\mathrm{KBr} \mathrm{cm}{ }^{-1}\right): 3032,2925,2850,1683,1600$, 1595.

3d: R: 2- $\mathrm{NO}_{2}, \mathrm{C}_{23} \mathrm{H}_{17} \mathrm{~N}_{3} \mathrm{O}_{3} \mathrm{~S}_{2}$, mp. $210-212^{\circ} \mathrm{C}$, yield: $69 \%$. FT-IR $\left(\mathrm{KBr} \mathrm{cm}^{-1}\right)$ : 3032, 2920, 2840, 1699, 1600, $1521,1501,1320$.

3e: R: 2-F, $\mathrm{C}_{23} \mathrm{H}_{17} \mathrm{FN}_{2} \mathrm{OS}_{2}$, mp. $198-200^{\circ} \mathrm{C}$, yield: $72 \%$. FT-IR $\left(\mathrm{KBr} \mathrm{cm}{ }^{-1}\right): 3027,2916,2835,1681,1607$, 1511, 1485.

3f: R: 4- $\mathrm{NO}_{2}, \mathrm{C}_{23} \mathrm{H}_{17} \mathrm{~N}_{3} \mathrm{O}_{3} \mathrm{~S}_{2}, \quad$ mp. $230-231^{\circ} \mathrm{C}$, yield: 75\%. FT-IR (KBr):3025, 2921, 2875, 1697, 1599, 1517, 1516, 1340; ${ }^{1} \mathrm{H}-\mathrm{NMR}: 2.49$ (s, 3H, $\left.\mathrm{CH}_{3}\right)$; 3.97, $3.99\left(\mathrm{dd}, 2 \mathrm{H}, \mathrm{C}_{17}\right) ; 6.35$ : (s, H, C 5 ); 6.69-8.5 (m, for all aromatic proton); ${ }^{13} \mathrm{C}-\mathrm{NMR}: 21.5: \mathrm{CH}_{3} ; 33.3: \mathrm{C}_{17}$; $63.9: \mathrm{C}_{5} ; \quad 121.38: \mathrm{C}_{2,2^{\prime}} ; \quad 121.62: \mathrm{C}_{12} ; 122.8: \mathrm{C}_{15}$; $127.7: \mathrm{C}_{7,7^{\prime}} ; 128.21: \mathrm{C}_{14} ; 128.5: \mathrm{C}_{8,8^{\prime}} ; 129.6: \mathrm{C}_{3,3^{\prime}}$; $132.4: \mathrm{C}_{9} ; 135.5: \mathrm{C}_{13} ; 135.1: \mathrm{C}_{11} ; 141.2: \mathrm{C}_{6} ; 146.2:$ $\mathrm{C}_{6} ; 148.1: \mathrm{C}_{1} ; 152.31: \mathrm{C}_{16} ; 158.0: \mathrm{C}_{10} ; 170.6: \mathrm{C}_{18}$, $(-\mathrm{C}=\mathrm{O})$; Dept-135:21.5: $\mathrm{CH}_{3} ; 33.3: \mathrm{C}_{17} ; 63.9: \mathrm{C}_{5}$; $121.38: \mathrm{C}_{2,2^{\prime}} ; 121.62: \mathrm{C}_{12} ; 122.8: \mathrm{C}_{15} ; 127.7: \mathrm{C}_{7,7^{\prime}}$; $128.2: \mathrm{C}_{14} ; 128.5: \mathrm{C}_{8^{\prime}, 8} ; 129.6: \mathrm{C}_{3^{\prime}, 3}$. 


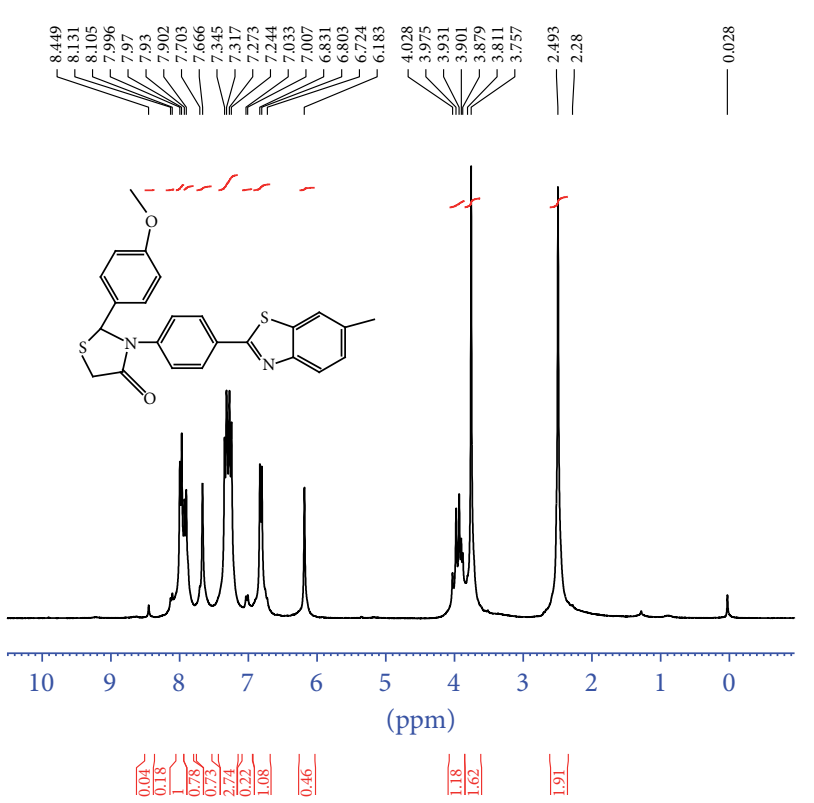

FIgURE 4: ${ }^{1} \mathrm{H}-\mathrm{NMR}$ spectrum of compound (3g).

3g: R: 4- $\mathrm{OCH}_{3}, \mathrm{C}_{24} \mathrm{H}_{20} \mathrm{~N}_{2} \mathrm{O}_{2} \mathrm{~S}_{2}, \mathrm{mp} .180-182^{\circ} \mathrm{C}$, yield: 64\%. FT-IR (KBr):3020, 2995, 2917, 2845, 1668, 1590, 1510, 1253, 1024; ${ }^{1} \mathrm{H}-\mathrm{NMR}: 2.56$ : (s, 3H, $\left.\mathrm{CH}_{3}\right) ; 3.75\left(\mathrm{~s}, 3 \mathrm{H},-\mathrm{OCH}_{3}\right) ; 3.9,3.97$ (dd, $\mathrm{CH}_{2}$, $\left.\mathrm{C}_{17}\right) ; 6.18:\left(\mathrm{s}, \mathrm{H}, \mathrm{C}_{12}\right) ; 6.7\left(\mathrm{~d}, 2 \mathrm{H}, \mathrm{C}_{2,2^{\prime}}\right) ; 6.8-8.4$ (m, for aromatic ring); ${ }^{13} \mathrm{C}-\mathrm{NMR}: 21.56: \mathrm{CH}_{3}$; 33.68: $\mathrm{C}_{17} ; 55.25:-\mathrm{OCH}_{3} ; 65.02: \mathrm{C}_{5} ; 114.34: \mathrm{C}_{2,2^{\prime}}$; 121.38: $\mathrm{C}_{12} ; 122.72: \mathrm{C}_{15} ; 125.61: \mathrm{C}_{7,7^{\prime}} ; 128.01$ : $\mathrm{C}_{14} ; 128.4: \mathrm{C}_{8,8^{\prime}} ; 130.56: \mathrm{C}_{4} ; 130.8: \mathrm{C}_{3^{\prime}, 3} ; 131.93:$ $\mathrm{C}_{9} ; 135.26: \mathrm{C}_{13} ; 135.52: \mathrm{C}_{11} ; 139.65: \mathrm{C}_{6} ; 152.2:$ $\mathrm{C}_{16} ; 160.04: \mathrm{C}_{1} ; 165: \mathrm{C}_{10} ; 171: \mathrm{C}_{18} ;$ Dept-135: 21.56: $\mathrm{CH}_{3} ; 33.68: \mathrm{C}_{17} ; 55.25:-\mathrm{OCH}_{3} ; 65.02: \mathrm{C}_{5}$; $114.34: \mathrm{C}_{2,2^{\prime}} ; 121.31: \mathrm{C}_{12} ; 122.73: \mathrm{C}_{15} ; 125.61: \mathrm{C}_{7,7^{\prime}}$; $128.01: \mathrm{C}_{14} ; 128.4: \mathrm{C}_{8,8^{\prime}} ; 130.8: \mathrm{C}_{3^{\prime}, 3}$.

3h: R: 4- $\mathrm{CH}_{3}, \mathrm{C}_{24} \mathrm{H}_{20} \mathrm{~N}_{2} \mathrm{OS}_{2}$, mp. 191-193 ${ }^{\circ} \mathrm{C}$, yield: $67 \%$. FT-IR $\left(\mathrm{KBr} \mathrm{cm}^{-1}\right)$ : 3030, 2919, 2860, 1672, 1605, $1485,1382$.

3i: R: $-\mathrm{CHO}, \mathrm{C}_{24} \mathrm{H}_{18} \mathrm{~N}_{2} \mathrm{O}_{2} \mathrm{~S}_{2}, \quad \mathrm{mp} . \quad 310-312^{\circ} \mathrm{C}$, yield: 76\%. FT-IR (KBr): 3034, 2923, 2855, 1701, 1605, 1598, 1591.

3j: R: 3- $\mathrm{NO}_{2}, \mathrm{C}_{23} \mathrm{H}_{17} \mathrm{~N}_{3} \mathrm{O}_{3} \mathrm{~S}_{2}$, mp. $180-182^{\circ} \mathrm{C}$, yield: 70\%. FT-IR $\left(\mathrm{KBr} \mathrm{cm}^{-1}\right)$ : 3032, 2917, 2860, 1682, 1600, 1519, 1486, 1481, 1369.

\section{Results and Discussion}

4-(6-methylbenzo[d]thiazol-2-yl)benzenamine (1) was treated with different substituted benzaldehydes to produce a series of Schiff base compounds $(2 a-j)$. The Schiff bases were subjected to cyclocondensation reactions with 2mercaptoacetic acid in benzene to produce a series of new thiazolidin-4-one derivatives $(3 a-j)$, Scheme 1.

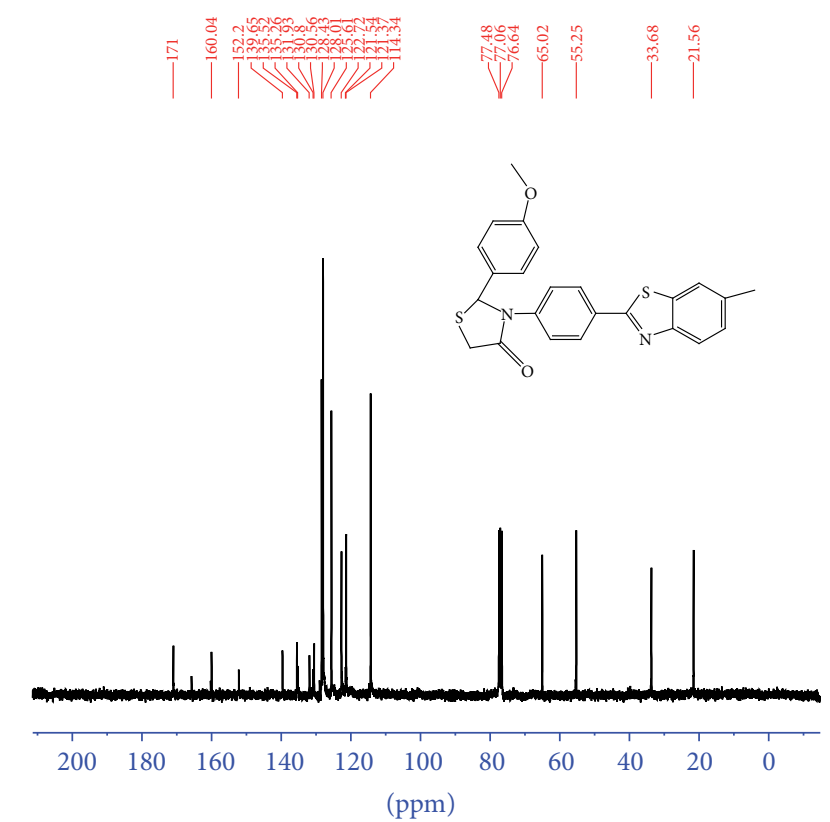

Figure 5: ${ }^{13} \mathrm{C}$-NMR spectrum of compound (3g).
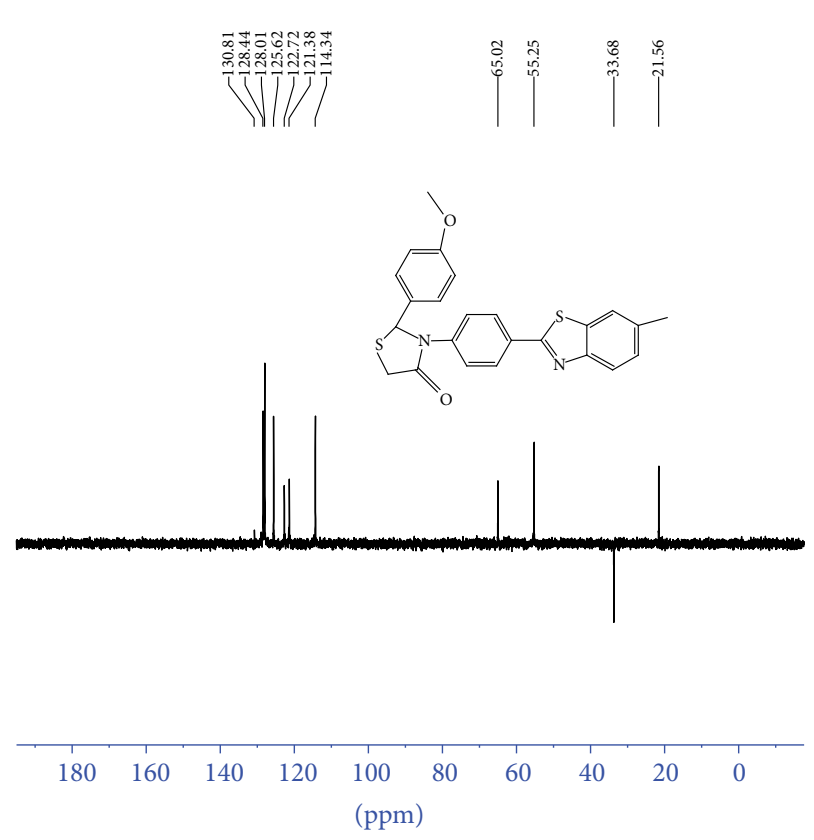

FIGURE 6: Dept-135 spectrum of compound (3g).

In the study of the influence of the substituents of the substituted benzaldehydes on the rate of the formation and yield of imine products, any factor increasing the electrophilicity of the carbonyl carbon of benzaldehyde should increase reactivity. In contrast, substituents reducing electrophilicity should reduce reactivity. In contrast to electron-withdrawing substituents the electron-releasing substituents, release electrons to the ring and disperse the positive charge on carbonyl carbon, as a result the rate and the yield of imine reduce. 
TABLE 1: Antibacterial activity of some prepared imines and thiazolidin-4-ones with inhibition zone diameters in $(\mathrm{mm})$ scale against S.aureus and E.coli bioorganisms.

\begin{tabular}{lcc}
\hline Product no. & E.coli $\mathrm{G}(-\mathrm{ve})$ & S.aureus $\mathrm{G}(+\mathrm{ve})$ \\
\hline TMP & 40 & 30 \\
2f & 40 & 30 \\
2g & 35 & 30 \\
$3 \mathrm{f}$ & 40 & 30 \\
3b & 35 & 30 \\
$3 \mathrm{~h}$ & 40 & 35 \\
$3 \mathrm{~g}$ & 38 & 30 \\
\hline
\end{tabular}

The chemical structures of the synthesized compounds were confirmed by IR, ${ }^{1} \mathrm{H}-\mathrm{NMR}$ and ${ }^{13} \mathrm{C}$-NMR, and Dept135. The FT-IR spectra of the synthesized imines $(2 \mathrm{a}-\mathrm{j})$ showed the disappearance of amine and carbonyl bands and appearance of $\mathrm{C}=\mathrm{N}$ group band around $1620 \mathrm{~cm}^{-1}$ considered as a good evidence for the formation of imine groups.

The ${ }^{1} \mathrm{H}$-NMR spectra of all imines, (Figure 1) show a singlet signals at $8.4 \mathrm{ppm}$ [21], belongs to imine or azomethene $(\mathrm{CH}=\mathrm{N}-)$ group, with a characteristic bands for each compound such as compound (2b) which has showed a singlet at (2.5 ppm) due to three protons of $\mathrm{CH}_{3}$ group, compound ( $2 \mathrm{~g}$ ) showed a singlet at $3.9 \mathrm{ppm}$ which belongs to three protons of $\mathrm{OCH}_{3}$ group, and compound (2i) showed a singlet at 10.1 for CHO group. The ${ }^{13} \mathrm{C}-\mathrm{NMR}$ and Dept spectra (Figures 2 and 3) for each compound were matching perfectly with the expectations. The IR spectra of thiazolidin-4-ones showed a characteristic band at (1667-1699) $\mathrm{cm}^{-1}$ due to carbonyl group stretching of cyclic amides [22]. The disappearance of imine bands at $1620 \mathrm{~cm}^{-1}$ indicates the formation of thiazolidin-4-one ring. The ${ }^{1} \mathrm{H}$-NMR spectra of thiazolidin4-ones, (Figure 4), showed characteristic signals dd at (3.8, 4) and a singlet at $6 \mathrm{ppm}$ corresponding to proton of $\mathrm{C}_{17}$ and $\mathrm{C}_{5}$ of thiazolidin-4-ones ring, confirming the nonequivalence of protons at $\mathrm{C}_{17}$ of the five-membered ring of thiazolidin4-ones, which appeared as two doublet to doublet (dd) and a singlet of monoproton of $\left(\mathrm{C}_{5}\right)$. Also as imines the ${ }^{13} \mathrm{C}$ NMR and Dept spectra (Figures 5 and 6 ) for each compound were matching perfectly with the expectations, and the Dept spectra for thiazolidin-4-ones showed a downward signal [23] for diprotonated carbon $\left(\mathrm{CH}_{2}\right)$ group at $-65 \mathrm{ppm}$ of the synthesized thiazolidin-4-one rings.

Antibacterial Activity. The antimicrobial activity of the synthesized compounds were screened against two types of bacteria Escherichia coli (gram negative) and Staphylococcus aureus (gram positive) by using the cup-plate agar diffusion method with $\mathrm{KBr}$ disc of compounds. The prepared discs were placed on the surface of the cultured media with each of the two bacteria incubated for 24 hours at $37^{\circ} \mathrm{C}$, and the results were monitored by measuring inhibition zones in $\mathrm{mm}$. The screening results are listed in (Table 1) and they show that most prepared compounds were sensitive against both types of bacteria. The antibacterial activity of these compounds shows similar activity with (TMP) trimethoprim antibiotic, which prevents infections of the urinary tract caused by bacteria.

\section{References}

[1] A. Echevarria, M. D. G. Nascimento, V. Gerônimo, J. Miller, and A. Giesbrecht, "NMR spectroscopy, hammett correlations and biological activity of some Schiff bases derived from piperonal," Journal of the Brazilian Chemical Society, vol. 10, no. 1, pp. 60-64, 1999.

[2] W. T. Gao and Z. Zheng, "Synthesis and characterization of chiral nitrobenzaldehyde-Schiff base ligands," Molecules, vol. 8, no. 11, pp. 788-792, 2003.

[3] K. M. Thaker, "Synthesis of 4-thiazolidinones and 2azetidinones bearing benzo(b) thiophenes nucleus as potential antitubercular andantibacterial agents," Indian Journal of Chemistry B, vol. 42, pp. 1544-1547, 2003.

[4] P. Ali, J. Meshram, and V. Tiwari, "Microwave mediated cyclocondensation of 2 -aminothiazole into $\beta$-lactam derivatives: virtual screening and in vitro antimicrobial activity with various microorganisms," International Journal of ChemTech Research, vol. 2, no. 2, pp. 956-964, 2010.

[5] D. Pareek, M. Chaudhary, and P. K. Pareek, "Synthesis of some bioactive 4-thiazolidinone derivatives incorporating benzothiazole moiety," Der Chemica Sinica, vol. 1, no. 3, pp. 22-35, 2010.

[6] S. Kasmi-Mir, A. Djafri, L. Paquin, J. Hamelin, and M. Rahmouni, "One-pot synthesis of 5-arylidene-2-imino-4thiazolidinones under microwave irradiation," Molecules, vol. 11, no. 8, pp. 597-602, 2006.

[7] B. Samia, B. Yamina, K. B. Rachedine, K. S. Nedjar, M. Poulain, and D. Elisabet, "A convenient one pot preparation of 4thiazolidinones from Enaminolactones," Org Commun, vol. 3, no. 1, pp. 8-14, 2010.

[8] K. M. Mistry and K. R. Desal, "Synthesis of novel heterocyclic 4-thiazolidinone derivatives and their antibacterial activity," $E$ Journal of Chemistry, vol. 1, no. 4, pp. 189-193, 2004.

[9] K. H. Patel and A. G. Mehta, "Synthesis of novel azetidinone and thiazolidinones derivatives and evaluation of their antimicrobial efficacy," E-Journal of Chemistry, vol. 3, no. 11, pp. 103-109, 2006.

[10] N. B. Patel and F. M. Shaikh, "Synthesis of New Pyridine Based 4-Thiazolidinones Incorporated Benzothiazoles and Evaluation of Their Antimicrobial Activity," Journal of Sciences, Islamic Republic of Iran, vol. 21, no. 2, pp. 121-129, 2010.

[11] P. Sharma, B. Shrivastava, H. S. Lamba, J. Sharma, and L. Sharma, "Synthesis and Pharmacological Study of 4Thiazolidinone Derivatives," Pharmacie Globale, vol. 3, no. 9, pp. 1-6, 2010.

[12] D. Patel, P. Kumari, and N. Patel, "Synthesis, characterization and biological evaluation of some thiazolidinone derivatives as antimicrobial agents," Journal of Chemical and Pharmaceutical Research, vol. 2, no. 5, pp. 84-91, 2010.

[13] M. K. Ahirwar and S. P. Shrivastava, "Synthesis and biological activity of some 2-( $2^{\prime}$-(substituted phenyl-4-thiazolidinone-3yl)-1' $3^{\prime}$-isoxazol-4-yl)aminoquinoline derivatives," E-Journal of Chemistry, vol. 8, no. 2, pp. 931-937, 2011.

[14] M. T. Shreenivas, B. P. Chetan, and A. R. Bhat, "Synthesis and Pharmacological Evaluation of Certain Schiff Bases and Thiazoldine Derivatives as AT1 Angiotension-II(AII) Receptor Antagonists," Journal of Pharmaceutical Science and Technology, vol. 1, no. 2, pp. 88-94, 2009. 
[15] V. K. Tirlapur and T. Tadmalle, "Synthesis and insecticidal activity of 1,2,4-triazolo-thiazolidin-4-one derivatives," Der Pharmacia Sinica, vol. 2, no. 1, pp. 135-141, 2011.

[16] A. Gursoy and N. Terzioglu, "Synthesis and isolation of new regioisomeric 4-thiazolidinones and their anticonvulsant activity," Turkish Journal of Chemistry, vol. 29, pp. 247-254, 2005.

[17] H. H. Parekh, K. A. Parikh, and A. R. Parikh, "Synthesis of some 4-thiazolidinone derivatives as antitubercular agents," Journal of Sciences, Islamic Republic of Iran, vol. 15, no. 2, pp. 143-148, 2004.

[18] A. S. Nagarajan, S. Kamalraj, J. Muthumary, and B. S. R. Reddy, "Synthesis of biologically active benzothiazolc substituted thiazolidinone derivatives via cyclization of unsymmetrical imines," Indian Journal of Chemistry B, vol. 48, no. 11, pp. 1577-1582, 2009.

[19] S. Ramachandran, P. Shanmugapandiyan, and C. N. Nalini, "Synthesis and anti-microbial evaluation of N-(2-(4-substituted phenyl)-4- oxothiazolidine-3-Yl) isonicotinamide derivative," International Journal of Pharma Sciences and Research, vol. 2, no. 6, pp. 1564-1568, 2011.

[20] D. Patel, P. Kumari, and N. Patel, "Synthesis, characterization and biological evaluation of some thiazolidinone derivatives as antimicrobial agents," Journal of Chemical and Pharmaceutical Research, vol. 2, no. 5, pp. 84-91, 2010.

[21] A. J. Hussein and H. J. Azeez, "Synthesis and spectroscopic characterization of some new azo-thiazolidinone derivatives," Der Chemica Sinica, vol. 2, no. 5, pp. 136-146, 2011.

[22] K. H. Patel and A. G. Mehta, "Synthesis and antifungal activity of azetidinone and thiazolidinones derivatives of 2-amino-6-(2naphthalenyl)thiazolo[3,2-d]thiadiazole," E-Journal of Chemistry, vol. 3, no. 13, pp. 267-273, 2006.

[23] L. D. Field, S. Sternhell, and J. R. Kalman, Organic Structures from Spectra, John Wiley \& Sons, 4th edition, 2005. 

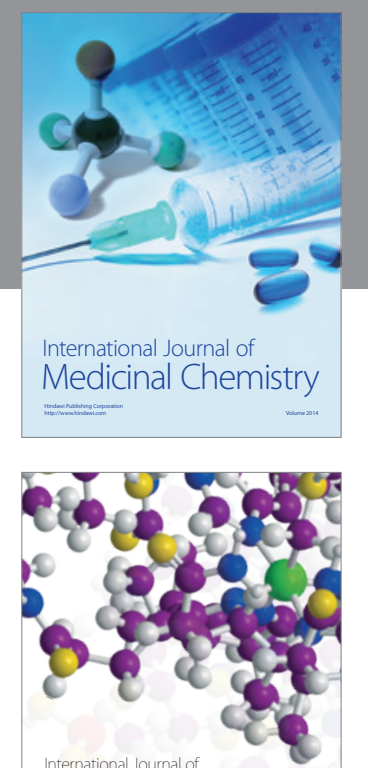

\section{Carbohydrate} Chemistry

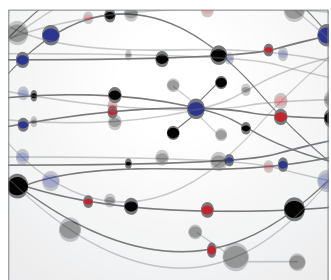

The Scientific World Journal
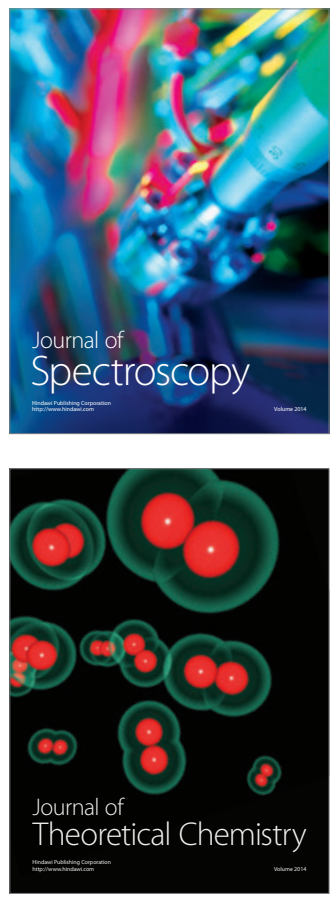
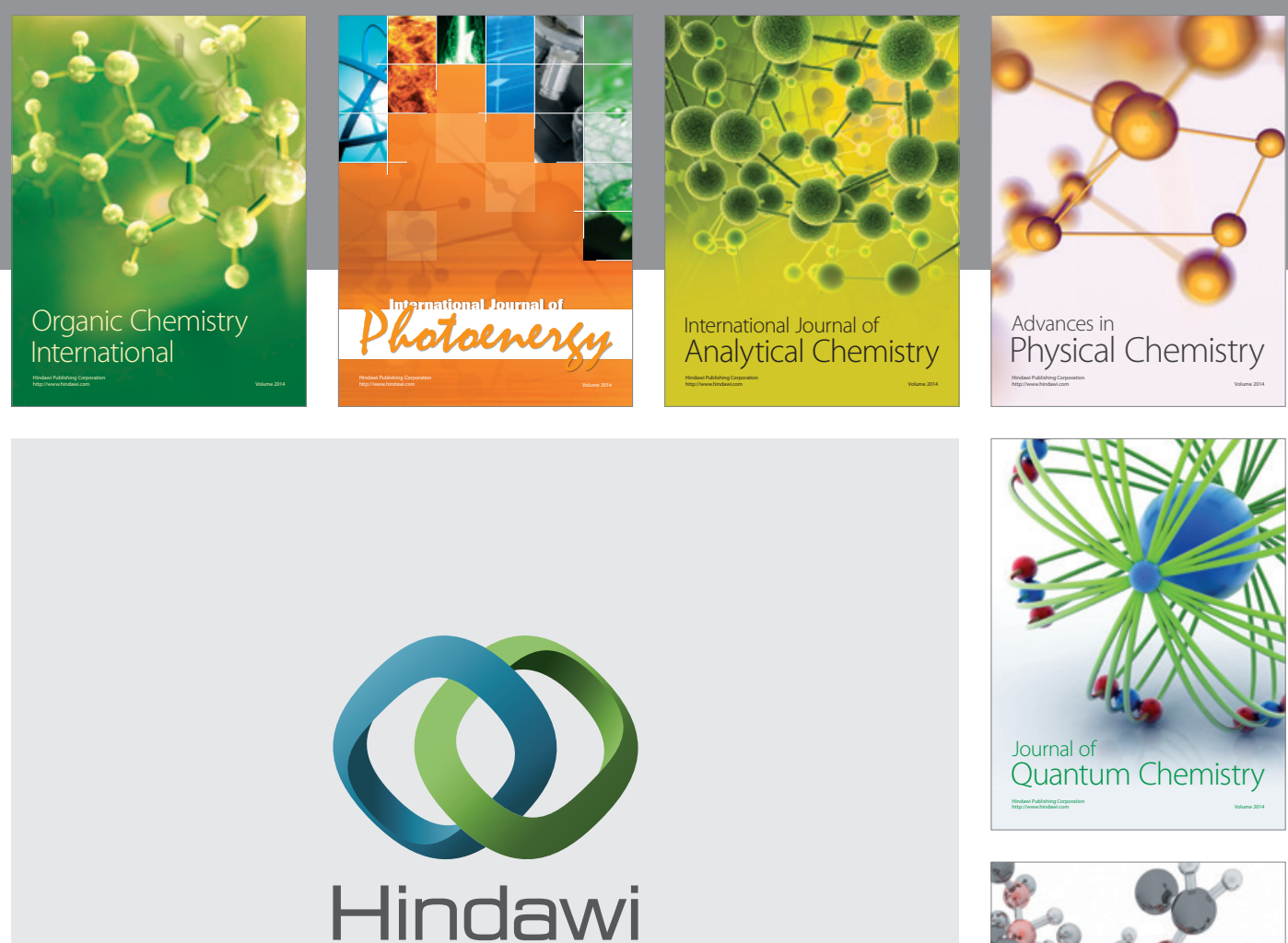

Submit your manuscripts at

http://www.hindawi.com

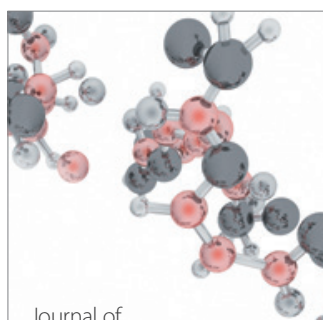

Analytical Methods

in Chemistry

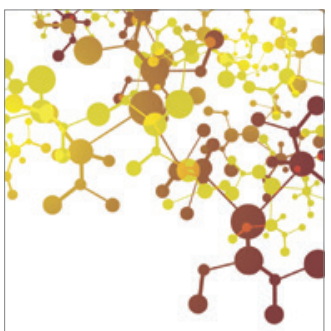

Journal of

Applied Chemistry

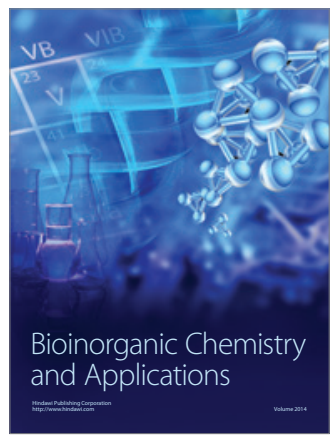

Inorganic Chemistry
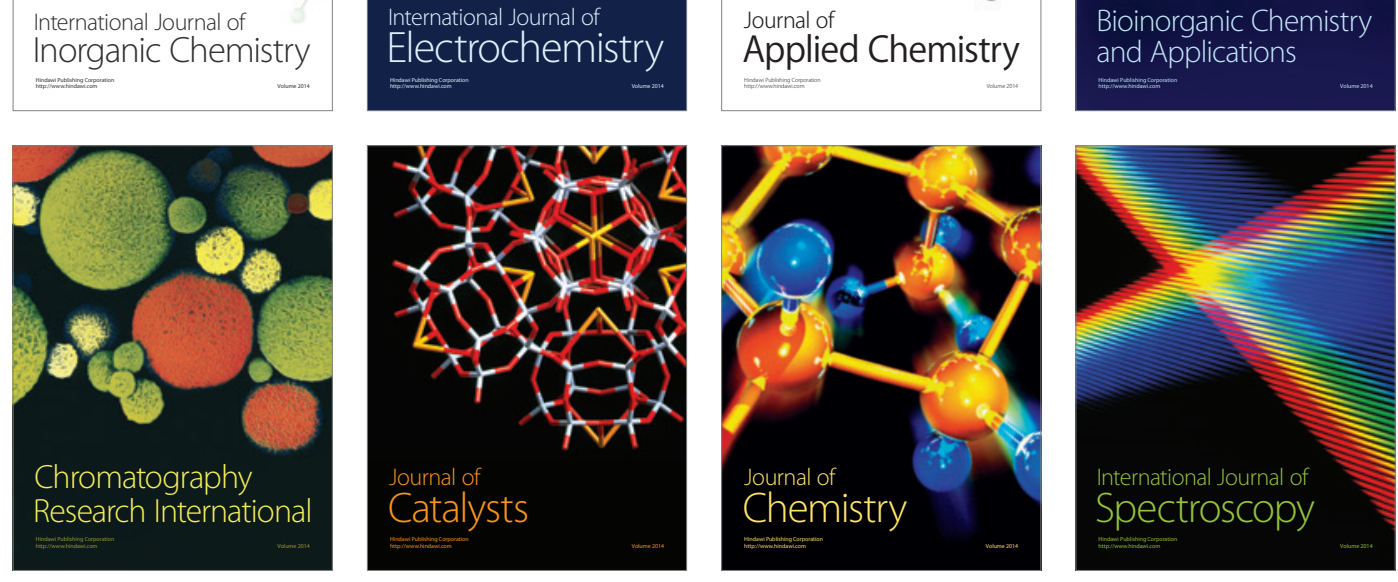